\title{
COOPERATION TOWARDS SUPPORTING DUAL EDUCATION SYSTEMS (VOCATIONAL EDUCATION)
}

\begin{abstract}
This article reports the results of research performed during the "DUAL. Transnational cooperation towards supporting dual education in vocational education and training institutions" (DUAL) project implemented by a consortium of labour market institutions located in Poland and Belgium. The aim of the research was to determine the status the attractiveness and quality of the current vocational education offered at the regional level, preparation of students for the transition from the education system to the local labour market, implementation of dual education by schools, and the required module in vocational counselling in schools in the Subcarpathian voivodeship, including in the context of counteracting NEET (i.e., not in employment, education or training) phenomenon. The research, carried out as part of the DUAL project, permitted identification of trouble spots within Subcarpathia in the context of vocational education, and the conclusions from the research will be used to support educational institutions as well as to construct recommendations for labour market institutions.
\end{abstract}

Keywords: dual education, vocational training, unemployed youth, labour market, NEET.

\section{INTRODUCTION}

Bringing vocational education closer to the requirements of the labor market is essential to increase its effectiveness. An effective solution to achieve this goal is to combine education at school with internships, apprenticeship, or other form of work within a company. It is the so-called "dual education system", which is very widespread in countries that are highly developed economically; such as Germany, Austria, Switzerland and France.

Dual education is not limited to secondary education. It is often implemented in higher education as practice-oriented university programmes (Alli, Nillson, 2015), or even in courses for youth who are learning English as their second language (Le Menestrel, 2020). A revival of enthusiasm for dual vocational education and training can be observed in the European Union since the start of the global financial crisis (Šćepanović, Martín Artiles, 2020).

${ }^{1}$ Damian Liszka, PhD, Institute of Philosophy and Sociology, The Pedagogical University of Krakow; e-mail: damian.liszka@up.krakow.pl. ORCID: 0000-0002-2192-1672.

2 Paweł Walawender, PhD, Institute of Philosophy and Sociology, The Pedagogical University of Krakow; e-mail: pawel.walawender@up.krakow.pl (corresponding author). ORCID: 0000-0003$-4573-5759$. 
Dual vocational education is based on the close cooperation between two partners: the company and the vocational school. The partners share the responsibilities related to the education of the students. The school imparts theoretical knowledge and the company assumes the responsibility for practical training. Students spend several days a week within the company, where they learn and perform tasks similar to those they will occupy themselves with in the future, once they become full-fledged employees of companies (German dual education system, http).

There are some terminological inaccuracies in Polish publications and scientific studies which hinder developing an unambiguous position in relation to the definition of dual education (Bura, Barańska, Cieślik, 2014).

The common basis for defining dual education is acknowledgment - its "duality", understood as:

- the duality of places of learning (schools / organizers of vocational education and training as well as companies providing training), which are jointly responsible for the implementation of theoretical and practical training,

- the duality of entities (public and private ones) that are jointly responsible for policy and practice in the field of vocational education and training.

The basis for the definitions used in European and international literature is the duality of places of learning (Nogueira, 2014).

According to UNESCO, "the dual education system is designated »dual « as within its framework the process of apprenticeships in a company as well as vocational training in a vocational school are combined into one course" (Nogueira, 2014).

In turn, according to Cedefop, the term "dual education system" can be used interchangeably with the terms "alternate training", "apprenticeship" or "work-based learning" (Nogueira, 2014).

The difficult situation of young people in the labor market requires solutions that support their transition from education to employment. There are high hopes for the advancement of a work-based learning system in the workplace. Although there are work-based learning programs in place in all EU member states, their scale, popularity and results vary considerably. To date, there is no single apprenticeship model and in most member states this system is definitely not the primary pathway to vocational education and training (German dual education system, http).

One of the attempts to solve this problem was the project entitled "DUAL. Transnational cooperation towards supporting dual education in vocational education and training institutions"3 carried out by a consortium of labor market institutions from Poland and Belgium ${ }^{4}$. Its aim was to develop and implement solutions supporting the adaptation of

${ }^{3}$ Project No. POWR.04.03.00-00-W338/16, co-financed by the European Union under the European Social Fund.

${ }^{4}$ Project "DUAL. Transnational cooperation towards supporting dual education in vocational education and training institutions" (DUAL) was carried out in the period between $1^{\text {st }}$ August 2017 to $30^{\text {th }}$ April 2020 by the leader of Educare Et Servire Foundation, Vlaams Agentschap voor Ondernemersvorming - SYNTRA Vlaanderen (transnational partner, a Belgian government organization), as well as national partners: BD Center sp. z o. o. (until $31^{\text {st }}$ December 2018), Pedagogical University of Krakow (from $18^{\text {th }}$ January 2019). Its goal was for at least 30 entities from 16 voivodeships in Poland to develop and implement new solutions, supporting the adjustment of vocational education and training systems to the needs of the labor market, facilitating the transition of students from vocational schools to the employment stage, and aimed at assisting 
vocational education and training systems to the needs of the labor market, facilitating the transition of vocational school students from the education stage to the employment stage. The focus of attention for implementers of the project included individuals in the NEET category ${ }^{5}$.

One of the initial stages of the project's implementation was the research stage. The research pertained to Poland and was aimed at determining the status quo in terms of: the attractiveness and quality of vocational education offered at the regional level, the preparation of students for the transition from the educational system to the local labor market, the implementation by schools of the idea of dual education, as well as the an obligatory module on career counseling in schools within the Subcarpathian voivodeship, including in the context of counteracting the NEET phenomenon. The purpose of this article is to present the conclusions of these analyses.

As a result of taking up such extensive research problems, the results and conclusions presented in this study only cover topics related to vocational education. On the other hand, topics related to career counseling in schools, career development paths chosen by students and their preparation for work in real employment conditions, as well as the NEET phenomenon may be the subject of a separate analysis. The aforementioned issues were researched in the DUAL project, but the interpretation of the results is not part of this article.

\section{METHODOLOGICAL ASSUMPTIONS AND THE RESEARCH SAMPLE}

The research phase of the project was carried out in the period from November 1, 2017 to March 31, 2018 in Subcarpathian voivodeship. The methodology was applied based on the concept of triangulation (combining research techniques). The following techniques were employed:

a) analysis of the data of existing educational documentation (desk research), primarily regarding the vocational education system and the situation in the labor market in Poland,

b) moderated discussions during six focus group interviews (FGIs) with employees of educational, counseling, and career counseling institutions $(n=33)$, as well as five FGIs with young people: students, graduates, including those belonging to the NEET category within the ages of $18-29(n=40)$, from the Subcarpathian voivodeship area.

The common denominator of the research was determination of the existing state: the attractiveness and quality of vocational education offered at the regional level, the preparation of students for their transition from the education system to the local labor market, the implementation of the idea of dual education by schools, as well as the implementation of an obligatory module on career counseling in schools in Subcarpathian, including in the context of counteracting the NEET phenomenon. The analysis of the material obtained during the research took place from January 15, 2021 to February 28, 2021 using a secondary data analysis (desk research) method. This is a social research technique that assumes the analysis of existing and available data and is not related to the acquisition of new information, but to the organizing, processing, and analysis of the collected data, both external and internal (Boguszewski, Makowska, 2013, in: Chmiel, 2018).

so-called NEET youth over 18 years of age in acquiring professional qualifications. Ultimately, the solutions were implemented by 75 institutions.

5 More on this topic: (Liszka, Walawender, 2021). 
The desk research report on dual education within vocational training and educational institutions by Chmiel was formulated in March 2018. The subject of the analysis was specifically the following issues:

a) the situation of Polish vocational education before 1999;

b) the assumptions of the 1999 reform of the education system (in the context of changes in vocational education);

c) the state of Polish vocational education after political changes;

d) the assumptions of the latest education system reform in 2017 (mainly in the field of vocational education);

e) the principles for the functioning of the dual education model (Chmiel, 2018).

Focus Group Interviews with 33 employees of institutions, related to education or vocational activation from Subcarpathian voivodeship, were carried out in Rzeszów in the period from January 30, 2018 to February 16, 2018. The FGI technique is one of the qualitative methods used in social research, as opposed to quantitative methods such as surveys which use standardized questionnaires and conduct research on large samples. A group interview of intentionally selected respondents in the proposed category (meaning they were not a statistical representation of any population) and situated in one place enables the collection of empirical data generated through a discussion with the participation of the researcher (moderator). The discussion may be recorded on a voice recorder or a video camera. Data obtained in this way can be analyzed in many aspects with the use of appropriate tools (Maison, 2001, in: Broszkiewicz, 2018a).

Each of the 6 FGI groups (consisting of 5 or 6 participants) was selected in such a way that the respondents constituting it possessed experience in with: students and graduates of VET schools, and NEET youth between the ages of 18 to 29. Recruitment for the study was carried out using publicly available lists of institutions.

Research problems (in the context of vocational education) focused primarily on issues such as:

a) obtaining participants' views on the vocational education system developed after the 1999 reform;

b) verifying the level of knowledge on the topic of education system reform assumptions in 2017;

c) assessment of the dual education system (advantages and disadvantages);

d) identification of potential threats in the context of achieving the goals of the dual education system (Broszkiewicz, 2018a).

The interview was based on a partially structured non-questionnaire discussion guide comprised of 12 questions (sample questions connected to VET education) asked during FGIs:

- How do you assess the level of adaptation of the current (i.e. shaped after the 1999 reform) education system in our country (including education at its respective levels) to the requirements of the modern labor market?

- In this context, what were the advantages of this system and what were the disadvantages?

- What, according to you, are the reasons for undertaking education reform that introduces dual education, as well as the purposes underlying these changes?

- What are the advantages of introducing a dual education system? What are the expected benefits of its introduction? 
- Which social categories can benefit most from its introduction?

- Which trades can specifically benefit from this type of solution?

- What are the possible disadvantages of a dual education system?

- What elements are missing in the assumptions adopted by this system?

- What might the potential negative consequences of its introduction be?

- What barriers may stand in the way of achieving the goals that are set for a dual form of education?

- What measures can be taken to remedy these problems? (Broszkiewicz, 2018a).

The participants constituted a group diversified in terms of basic socio-demographic characteristics, such as: age, gender, place of residence, and workplace (see Table 1). Thanks to such a diversity of research participants, learning the opinions of respondents from very different perspectives was made possible.

Table 1. Characteristics of the FGI participants (institution employees)

\begin{tabular}{|l|l|c|c|}
\hline \multicolumn{2}{|c|}{ Characteristic } & n & \% \\
\hline \multirow{2}{*}{ Sex } & Female & 30 & 90.9 \\
\cline { 2 - 4 } & Male & 3 & 9.1 \\
\hline \multirow{2}{*}{ Age } & ISCED 5-8 & 32 & 96.7 \\
\hline & ISCED 4 & 1 & 3.3 \\
\hline \multirow{2}{*}{$\begin{array}{l}\text { Residency } \\
\text { (Subcarpathia) }\end{array}$} & $18-29$ & 7 & 21.2 \\
\hline \multirow{3}{*}{ Workplace } & $30-49$ & 18 & 54.6 \\
\cline { 2 - 4 } & S0-64 & 8 & 24.2 \\
\cline { 2 - 4 } & Rural area & 30 & 90.9 \\
\cline { 2 - 4 } & $\begin{array}{l}\text { Public institution - VET school } \\
\text { counseling center psychological and pedagogical }\end{array}$ & 3 & 9.1 \\
\cline { 2 - 4 } & Public institution - district job center & 2 & 3.0 \\
\cline { 2 - 4 } & $\begin{array}{l}\text { Non-governmental organization - vocational } \\
\text { training and professional activation institution }\end{array}$ & 6.0 \\
\cline { 2 - 4 } & $\begin{array}{l}\text { Commercial enterprise - vocational training and } \\
\text { professional activation institution }\end{array}$ & 12 & 36.2 \\
\hline
\end{tabular}

Source: Own study based on research results.

The 5 Focus Group Interviews (FGIs) totaling 40 respondents: VET students $(\mathrm{n}=14)$, VET graduates $(\mathrm{n}=15)$ and $18-29$ year old NEET youth $(\mathrm{n}=11)$ residing in the Subcarpathian area, were carried out in Rzeszów between the 14th of February 2018 and the 20th of March 2018. Each FGI group consisted of 8 participants. Survey respondents were selected from among candidates who, on the day of the study, were students or graduates of the vocational education system, or who had previously attended such a system and belonged to the NEET category (NEET status had priority in determining the respondent's status). Here, the "NEET" acronym refers to an individual who was not employed, not participating in the education system, and did not participate in additional training courses at least 4 weeks before participating in the study (Liszka, Walawender, 2018). The main sampling technique was RDS (Respondent Driven Sampling), which is an extension of the "snowball sampling" method. It consists in the recruiter attempting to reach 
several people who meet the criteria for participating in the project, in two/three different peer groups. These people (the so-called "seeds") suggest subsequent potential candidates from their group.

Research problems related to vocational education focused mainly on issues such as:

a) overall assessment of the level of education in schools being attended or were attended by the respondents;

b) respondents' experiences with practical education;

c) assessment of the assumptions of the 2017 education reform (primarily in the context of vocational education) (Broszkiewicz, 2018b). The interview was based on a partially structured non-questionnaire discussion guide with 11 questions. Sample questions connected to vocational education training asked during the focus group interviews:

- How do you generally assess the level of education in the schools from which you graduated?

- In your opinion, what are the advantages and disadvantages of such schools? What could possibly be improved in their operation?

- Did you have the opportunity to participate in apprenticeships during your education? If so, how would you rate it in terms of size, organization, teacher preparation and content?

- If not, do you notice the lack of such activities?

- How do you assess the assumptions of the reform enabling vocational education at two levels, i.e., in 1st and 2nd degree trade schools?

- In your opinion, what should the relationship between schools and employers be, i.e., how should this cooperation proceed in order for such an education system to be effective? (Broszkiewicz, 2018b).

- The vocational education training students, graduates, and NEET youth participants constituted a group diversified in terms of basic socio-demographic characteristics (see Table 2).

Table 2. Characteristics of the FGI participants (VET students, graduates, and NEET youth)

\begin{tabular}{|l|l|c|c|}
\hline \multicolumn{2}{|c|}{ Characteristic } & n & \% \\
\hline \multirow{2}{*}{ Sex } & Female (VET students/VET graduates/NEET) & $18(6 / 7 / 5)$ & 45.0 \\
\cline { 2 - 4 } & Male (VET students/VET graduates/NEET) & $22(8 / 8 / 6)$ & 55.0 \\
\hline Education level & ISCED 5-8 & 8 & 20.0 \\
\hline & ISCED 4 & 8 & 20.0 \\
\hline & ISCED 3 & 9 & 22.5 \\
\hline \multirow{2}{*}{ Age } & ISCED 2 & 15 & 37.5 \\
\hline & $18-24$ & 25 & 62.5 \\
\hline \multirow{2}{*}{$\begin{array}{l}\text { Residency } \\
\text { Subcarpathia) }\end{array}$} & $25-29$ & 15 & 37.5 \\
\hline \multirow{2}{*}{ Educational status } & City area & 28 & 70.0 \\
\cline { 2 - 4 } & Rural area & 12 & 30.0 \\
\cline { 2 - 4 } & VET students & 14 & 35.0 \\
\cline { 2 - 4 } & VET graduates (working or studying) & 15 & 37.5 \\
\cline { 2 - 4 } & NEET & 11 & 27.5 \\
\hline
\end{tabular}

Source: Own study based on research results. 
After the interviews a total of 11 text transcriptions had been obtained from the FGIs. The transcriptions, as well as the written "desk research" report (Chmiel, 2018), have been used for conducting in-deep data analyses using the desk research method (by the authors).

\section{RESEARCH RESULTS}

\subsection{Changes in the structure of vocational education in Poland as a result of the 1999 reform}

The education reform of 1999 was aimed at, among others, the promulgation of general education in Poland as well as to increase the percentage of people with higher education in the society. As regards changes to the structure of formal education, a new type of school was introduced - middle school (Chmiel, 2018), obligatory after completing six years of primary school. In turn, after graduating from middle school, students could continue their education in 3-year general education or specialized high schools (vocational, completely eliminated from 2012 to 2015), 3 or 4-year technical high schools, 3-year basic vocational schools, or 3-year special education schools which prepared students with moderate or severe mental disabilities as well as students with multiple disabilities for work. After graduating from high school or technical high school, the graduate could commence with the matriculation examination ("matura" in Polish) and, after passing it, continue their schooling in higher education (Górecka, 2007). On the other hand, a graduate of a 3-year basic vocational school, in order to commence the matriculation examination and continue their studies, was required to first complete a 2-year supplemental general high school or a 3-year supplemental technical high school. The period of education necessary to commence the matriculation examination was therefore at least 2 years longer for graduates of basic vocational schools than for people choosing an educational path which included high school or technical high school immediately after graduating from middle school.

As part of the assumptions of the vocational education reform introduced in 2017, the period of schooling necessary for students of first degree (which replaced basic vocational schools) and second degree (introduced as a new type of school) vocational schools to commence the matriculation exam and then proceed to higher education was 5 years ( 3 years first degree +2 years second degree), similar to the period of study in a technical high school. This time frame is also comparable to the period of study in a 4-year high school; since a graduate of a second degree vocational school, in the course of their study, and in addition to a high school diploma, is able to obtain two professional qualifications, which is not possible for students during their studies in high school.

\subsection{Educational preferences of Poles after political transformation}

Education reform and other factors related to political transformation in Poland, such as the introduction of an "open market economy" and the bankruptcy of numerous state-owned enterprises, led to a decrease in the demand for highly qualified manual laborers and an increase in the demand for white-collar workers in newly created professions (Sondergaard et al., 2012). This triggered a change in the educational preferences of Poles and their shift from vocational education to schooling in general high schools and subsequently, at university, increasing the educational aspirations of society and the so-called "educational boom" consisting in the growing popularity of higher education in the country (Chmiel, 2018). Among EU countries, the largest increase in the percentage of people with higher 
education occurred- from $15 \%$ in 2001 to $42 \%$ in 2013 in the $25-34$ age group; whereas there was an increase from $24 \%$ to $36 \%$ in the entire EU27 (Lis, Miazga, 2014).

The respondents of the FGI interviews (employed individuals) supported the findings of the desk research. When asked to evaluate the education system that was shaped as a result of the 1999 reform, indicated that in their opinion the previous system rewarded aspirations for obtaining higher education while at the same time disparaged basic vocational education (a total of 11 individual statements from 6 FGI groups). According to the respondents, this was an unfavorable process, as it led to a situation in which obtaining a higher education diploma, no matter at what level or major, and also often chosen regardless of the candidate's skills or interests, resulted in an increase in the graduate's sense of social prestige. The assumptions of the 1999 reform, according to the respondents, also led to flooding of the Subcarpathian labor market with unemployed graduates of faculties for which employers had no need (e.g., law, administration, pedagogy), while on the other hand resulted in a reduction in the number of professionals in professions such as: locksmith, plasterer, sheet metal worker, welder, for which there was a real demand by employers (7 statements of employed individuals from 5 FGI groups). The above-mentioned conclusions regarding a lack of employees in the Subcarpathian labor market with practical skills related to the performance of a specific profession are also confirmed by a desk research report from 2018 (Chmiel, 2018).

The significant promulgation of general education after the 1999 reform and an increase in the percentage of Poles with higher education proceeded at the expense of lowering the status of vocational education. The share of students choosing general high schools increased between 1991 and 2010 from $23 \%$ to $41 \%$, while the percentage of students choosing basic vocational schools decreased from $43 \%$ to $15 \%$, whereby it was only $13 \%$ in 2005/06 (Chmiel, 2018). The percentage of technical high school graduates changed to a minor degree: between 1995 and 2013, it decreased from 25\% to 21\%, while the share of people with basic vocational education decreased from over $30 \%$ to $15 \%$ (Lis, Miazga, 2014). While in 1992 more students left basic vocational schools $(248,000)$ than in schools finishing with a matriculation examination $(220,000)$, in the following years the number of graduates from "matriculation" schools began to increase. In 2004, the number of high school graduates was over eleven times higher than the number of basic vocational school graduates $(458,000$ to 40,200$)$ (Tworzydło et al., 2018). The number of basic vocational schools in Poland also began to decline. In 2005, there were 5,009 of in total, while in 2015 - only 4,026 (Chmiel, 2018). Numerous stereotypes regarding vocational schools, as well as the students and teachers in these schools, spread throughout society. Vocational schools, as compared to general high schools, began to be perceived as schools of a lower caliber, intended for students who were less successful in their previous education. Likewise, the professionally active graduates of these schools began to be perceived as employees with low social prestige (Kwiatkowski, 2013). They earned the least because the market was saturated with laborers and craftsmen. Skills that could not be provided by vocational schools, such as a knowledge of foreign languages, began to be appreciated in the labor market (Szafraniec, 2011). It coincided with the demographic boom and the economic slowdown between 1997-2002 and the related liquidation of many jobs. Factories that maintained and provided employment for graduates collapsed (Chmiel, 2018). The survey respondents confirmed the findings from desk research of the existence of social stereotypes pertaining to vocational education ( 8 individual statements from employed individuals 
from 4 FGI groups; 7 statements from students, graduates and NEETs from 4 FGI groups). Indicated impositions on young people were:

- beliefs about the higher value of high schools than basic vocational schools;

- notions, that only individuals with such low ambitions, abilities, and skills attend such schools;

- assertions that nothing but those individuals who can't handle high school find their way into vocational schools.

It was also indicated that students of vocational schools were ashamed to talk about their education or learned profession, while students of middle schools who chose basic vocational schools in their further education paths were embarrassed to admit it to their peers.

\subsection{Operation of vocational schools and a decline in the importance of vocational education}

The loss of prestige of vocational education was caused not only by political transformation, the implementation of the assumptions of the education reform of 1999 or its stereotypical perception by society, but also by the activities of the bodies operating vocational schools. The offer proposed by school directors did not meet the real needs of the regional labor market or the demand reported by students (Szafraniec, 2011), and was created through a prism of the organizational, human resources and infrastructural capabilities of a given entity. This often led to a situation in which the curriculum included training in surplus occupations and industries with high unemployment (Chmiel, 2018). This is also confirmed by survey research conducted in 2015 by the Supreme Audit Office of 354 bodies operating schools, which indicated that the choice of fields of study was primarily determined by: available premises and equipment required for practical vocational training $(68 \%)$ as well as available teaching staff and their qualifications $(44 \%)$ (Supreme Audit Office, 2015). In view of such a supply-based model of organization of vocational education, students did not acquire the qualifications and practical skills expected by employers during their studies (Chmiel, 2018). In addition, the group interview respondents (employed individuals) indicated that the mismatch between the schools' offer and the real needs of employers, as well as the self-approach of vocational school staff (especially teachers) to changes in the labor market, described in one statement as their "reluctance to change", are problematic. This problem was indicated by a small number of respondents (a total of 4 individual statements from employed individuals from 2 FGI groups). Two respondents identified factors independent of schools that may also be the cause of the problem, such as the unpredictability of the labor market or too long a period of training, during which the demand for professions may change. On the other hand, FGI respondents who were students, graduates of vocational education and NEETs especially drew attention to the teachers, who for many years had provided the same scope of information and did not take into account the changes in a given industry as well as the labor market (4 statements from 2 FGI groups in total).

After the education reform of 1999, training in vocational schools was comprised of general, theoretical and vocational education, which could be implemented through theoretical training and apprenticeships. Practical skills classes, as part of the vocational education system, were usually conducted at the school (e.g., in workshops or school workrooms), while apprenticeships were most often organized at the employer's premises in real working conditions (Chmiel, 2018). In Subcarpathia, apprenticeships were relatively 
most often held in school workrooms (64\%). The exposure of the student to actual working conditions at the premises of the employer occurred in 54\% of the cases (Tworzydło et al., 2018). The FGI research participants clearly emphasized that the advantage of vocational schools when compared to schools providing only a general education program is the possibility of combining theoretical knowledge with the practical skills required by employers (statements appeared in each of the 6 FGI groups of working people and in 5 FGI groups of students, graduates and NEETs). In principle, both students and graduates assessed the practical skills training of a profession positively (in terms of the number of hours and quality), both in basic vocational schools and technical high schools (17 statements from 5 FGI groups). However, opinions about too many theoretical classes in relation to practical skills classes did occur (4 statements in 3 FGI groups). In the case of the respondents, apprenticeships were conducted mainly at school or educational institutions. However, the apprenticeships that took place beyond the school - in companies - were most appreciated (Broszkiewicz, 2018b). Nevertheless, students and graduates (including NEETs) drew attention to the numerous negative aspects in the organization of apprenticeships by schools, which were held in the workplace. These were: a mismatch between the apprenticeship program and the learning profile at school (8 statements in 4 FGI groups), instructing trainees to perform simple activities that do not require the qualifications acquired in vocational schools (for example: moving objects, sweeping the floor, digging holes in the ground, organizing documentation, making coffee), or also not delegating any tasks within the framework of the apprenticeship (8 statements in 4 FGI groups), or the excessive formalization of apprenticeship documentation (2 statements in 2 FGI groups).

\section{SUMMARY AND DISCUSSION}

On the basis of the analysis of the research carried out as part of the DUAL project in 2018, within the context of vocational education, some trouble spots were identified in Subcarpathia:

- the stereotypical perception of vocational school as the choice for less able students,

- adjusting the courses of study to the capabilities of a given school, and not to the actual needs of the regional labor market,

- the unsatisfactory preparation of vocational teachers to the ever-changing requirements in the field of learning a given profession,

- the unreasonable "theorization" of vocational education as well as too few courses of a practical vocational training nature,

- the improper organization of apprenticeships, based on the most straightforward work outsourced to apprentices, which do not allow for an increase in competences within a given profession as well as a mismatching between the apprenticeship program and the field of study,

- the promotion of education of a general nature at the expense of vocational training, which has led to a decline in the professional labor market as well as an increase in the number of unemployed higher education graduates.

The primary postulates of the 2017 reform include: increasing the prestige of vocational education in Poland, better adapting it to the needs of the labor market, increasing the number of hours of practical skills education, or implementing a dual education system in schools. The bodies operating vocational schools, apart from the systemically implemented 
solutions, may also employ other tools, including those developed under programs cofinanced by the European Social Fund (ESF). For instance, in Poland such programs include the so-called "Operational Knowledge, Education, and Development Program" (the acronym "POWER" in Polish) and Axis IV programs ("social innovations and transnational cooperation") managed by public Intermediate Bodies (IBs): The Ministry of Development (POWER 4.1 and POWER 4.2 intervention campaigns) and the Center for European Projects (POWER 4.3 Intervention campaign) (Liszka, Walawender, 2019). An example of such tools useful for supporting VET after the 2017 education reform in Poland may be developed in the DUAL project co-financed by the ESF under the POWER 4.3 campaign; 16 reports (1 report for each region of Poland) for VET teachers and school directors, as well as other vocational educational and training institutions with recommendations for the creation of new or modifications to existing curricula in order to fulfill the postulate of dual education and cooperation with local or regional employers, Practical Training Centers $(\mathrm{CKP})^{6}$. In each report, vocational school directors can find a detailed characteristic of the voivodeship (including a demographic portrait of the region, trends in the fields of education and upbringing, or the characteristics of the NEET group), a description of the economic situation in the voivodeship, the main assumptions of the 2017 education reform, or the results of a labor market analysis and curricula in terms of the requirements of the labor market. The recommendations regarding the creation or modification of curricula in accordance with the assumptions of the dual education system and the requirements of the labor market should be particularly useful for bodies operating vocational schools (updated in 2020). Recommendations taking into account the demand for professions or the developmental perspective of given trades, often indicating workplaces leading the way in a given region, conclusions from research conducted by voivodeship labor offices and local and regional strategies, as well as the infrastructure of schools and vocational training institutions. Reports, as well as other project products, are an example of good practice from Poland, as they are the effect of cooperation between commercial institutions, non-governmental organizations, and public entities (a higher learning institution from Poland and a government agency from Belgium) in the development of solutions supporting vocational education within the country.

The qualitative research findings emphasized some basic issues of the dual education system in Poland. The findings can be seen as an initial diagnosis of the current educational situation, and can provide guidelines to identify areas for some future research. Future research would be conducted as a representative quantitative research which would use more factors and would include different target groups (for example, employers, future employees, or policymakers) to include their input on the problems of dual education.

\section{REFERENCES}

Aili, C., Nilsson, L-E. (2015). Dual learning - a challenge for higher education in the new landscape of governance. "Tertiary Education and Management" No. 4 (21). DOI: 10.1080/13583883.2015.1068367.

Boguszewski, R., Makowska, M. (2013). Analiza danych zastanych - zagadnienia wstępne [Analysis of existing data - preliminary issues] [in:] Makowska, M., ed. Analiza danych

\footnotetext{
6 The reports are available open-access at: https://www.projektdual.pl/raporty-i-analizy
} (Access: 03.05.2021). 
zastanych. Przewodnik dla studentów [Analysis of existing data. Guide for students]. Warsaw: Scholar Publishing House.

Broszkiewicz, W. (2018a). Raport z badań FGI z osobami pracującymi przeprowadzonych w ramach projektu „DUAL. Ponadnarodowa wspótpraca $w$ kierunku wspierania ksztatcenia dualnego w placówkach szkolenia i ksztatcenia zawodowego" [FGI research report of employed individuals carried out within the "DUAL. Transnational cooperation towards supporting dual education in vocational education and training institutions" project], Rzeszów.

Broszkiewicz, W. (2018b). Raport z badań FGI z młodzieża (uczniami, absolwentami oraz tzw. NEET) przeprowadzonych $w$ ramach projektu „DUAL. Ponadnarodowa wspótpraca $w$ kierunku wspierania kształcenia dualnego $w$ placówkach szkolenia $i$ ksztatcenia zawodowego" [FGI research report of young people (students, graduates and the so-called NEETs) carried out within the ,DUAL. Transnational cooperation towards supporting dual education in vocational education and training institutions" project]. Rzeszów.

Bura, M., Barańska, W., Cieślik, W. (2014). Dual education system na przykładzie Politechniki Poznańskie [Dual education system in the case of Poznań University of Technology]. "Logistyka", No. 6.

Chmiel, Ł. (2018). Raport desk research nt. ksztatcenia dualnego w placówkach szkolenia $i$ ksztatcenia zawodowego opracowany $w$ ramach projektu „DUAL. Ponadnarodowa wspótpraca $w$ kierunku wspierania ksztatcenia dualnego $w$ placówkach szkolenia i ksztatcenia zawodowego" [Desk research report on dual education in VET institutions prepared within the „DUAL. Transnational cooperation towards supporting dual education in training facilities and vocational education" project]. [Access: 30.06.2021]. Access on the internet: https://www.projektdual.pl/assets/media/raport-desk-research-natemat-ksztalcenia-dualnego.pdf

German dual education system. [Access: 03.05.2021]. Access on the internet: https://www. goethe.de/ins/pl/pl/spr/eng/eib/dub.html?forceDesktop=1

Górecka, H. (2007). Szkolnictwo w Polsce w XIX i XX wieku [Education in Poland in the 19th and 20th centuries] [in:] Pilh T., ed. Encyklopedia Pedagogiczna XXI wieku [Pedagogical Encyclopedia of the 21st century], Vol. VI. Warsaw: Wydawnictwo Żak.

Kwiatkowski, S. M. (2013). Ksztatcenie zawodowe w formach szkolnych-wyzwania edukacyjne $i$ gospodarcze [Vocational education in school forms - educational and economic challenges]. "Educational Debate" No. 6.

Le Menestrel, S. (2020). Dual Language Learning and Educational Success for Youth. "Journal of Youth Development” No. 3 (15). DOI: 10.5195/jyd.2020.947.

Lis, M., Miazga, A. (2014). Czas na jakość w szkolnictwie zawodowym. [Time for quality in vocational education.], "IBS Policy Paper" No. 03/2014.

Liszka, D., Walawender, P. (2018). NEET Youth - the concept's presence in the European Union's Youth employment policy and why it is so problematic. "Humanities and Social Sciences" no. 4 (23). DOI: 10.7862/rz.2018.hss.77.

- (2019). Cross-sectoral cooperation towards a work-life balance. "Humanities and Social Sciences" No. 1 (26). DOI: 10.7862/rz.2019.hss.6.

(2021). The NEET youth program in the Subcarpathian voivodeship in the light of new research. "Humanities and Social Sciences” No. 1 (28). DOI: 10.7862/rz.2021.hss.05.

Maison, D. (2001). Zogniskowane wywiady grupowe. Jakościowa metoda badań marketingowych. [Focus group interviews. Qualitative method of marketing research]. Warsaw: PWN Publishing House. 
Nogueira, A. M. (2014). Briefing PE 529.082. [Access: 03.05.2021]. Access on the internet: https://www.europarl.europa.eu/RegData/etudes/BRIE/2014/529082/IPOL_BRI(2014) 529082_PL.pdf

Sondergaard, L., Murthi, M., Abu-Ghaida, D., Bodewig, Ch., Rutkowski, J. (2012). Skills, not just Diplomas. Managing Education for Results in Eastern Europe and Central Asia. Washington: The World Bank.

Supreme Audit Office (2015). Informacja o wynikach kontroli: system szkolnictwa zawodowego. [Information on audit results: vocational education system]. Warsaw: NIK.

Szafraniec, K., ed. (2011). Młodzi 2011 [Youth 2011]. Warsaw: KPRM.

Szymańska, A., ed. (2017). Analiza sytuacji szkolnictwa zawodowego w województwie tódzkim [Analysis of the situation of vocational education in Łódź Voivodeship]. Łódź: Regional Territorial Observatory of Łódź Voivodeship.

Šćepanović, V., Martín Artiles, A. (2020). Dual training in Europe: a policy fad or a policy turn? "Transfer: European Review of Labour and Research" No. 1 (26). DOI:10.1177/ 1024258919898317

Tworzydło, D., Lach, M., Lis, A., Szuba, P., Wasilewski, P., Zajic, M. (2018). Diagnoza sytuacji na rynku edukacyjnym $w$ województwie podkarpackim [Diagnosis of the situation on the educational market in Subcarpathian Voivodeship]. Rzeszów: Exacto.

DOI: $10.7862 /$ rz.2021.hss.14

The text was submitted to the editorial office: June 2021.

The text was accepted for publication: June 2021. 
